\title{
Dynamic Capabilities and Sustainable Performance of Selected Manufacturing Firms in Kenya
}

\author{
Gabriel Kitenga ${ }^{1^{*}}$, Dr. Anne W. Muchemi PhD², Dr. James M. Kilika PhD ${ }^{2}$ \\ ${ }^{1}$ PhD Candidate, Department of Business Administration, Kenyatta University \\ ${ }^{2}$ Lecturer, Department of Business Administration, Kenyatta University \\ ${ }^{3}$ Lecturer, Department of Business Administration, Kenyatta University
}

*Corresponding Author: Gabriel Kitenga, PhD Candidate, Department of Business Administration, Kenyatta University

\begin{abstract}
This study sought to examine how dynamic capabilities influence sustainable performance of selected manufacturing firms in Kenya. The specific objectives were to determine the relationship between adaptive capabilities and performance of selected manufacturing firms in Kenya; examine the relationship between marketing capabilities, alliancing capabilities and managerial capabilities on the performance of selected manufacturing firms in Kenya. The study was founded on positivist research philosophy and utilized a descriptive and explanatory survey design. Primary data collected from a population of 70 food manufacturing listed in the Kenya Association of Manufacturer's directory was analysed using multiple regression. The findings showed that there is a significant direct and positive relationship between dynamic capabilities and performance of food manufacturing firms in Kenya.
\end{abstract}

Keywords: Dynamic Capabilities, adaptive Capability, Marketing Capability, Alliancing Capability Managerial Capability, Firm Performance.

\section{INTRODUCTION}

Firm Performance is an important concept among business managers as well as scholars in business research. Concerns over firm performance are often motivated by the perception of threats to the durability of the firm. These concerns seem to be justified by the ever-growing competition for market and resources (Maltz, Shenar \& Reilly 2003). Globally, firms are looking for strategies that will enable them cope with the dynamic global competition (Easterby-Smith \& Prieto, 2008). The search for how to respond to environmental turbulence has led several scholars and strategic managers to view Dynamic Capabilities as being central to strategy and firm Performance (Teece, 2017).

Ambrosini and Bowman (2009) state that the role of dynamic capabilities is to impact on the firm's extant resource base and transform it in such a way that a new bundle or configuration of resources is created so that the firm can sustain or enhance its performance. According to Easterby-Smith and Prieto (2008), dynamic capabilities can take on multiple roles in organizations, such as changing resource allocations, organizational processes, knowledge development and transfer and decision making.

The Food Manufacturing is the largest manufacturing sub sector in Kenya. It contributes 30\% manufacturing GDP and $40 \%$ of all employees in the manufacturing sector (GOK, 2018). Increasing performance of food manufacturing firms is seen as a contributor to creation of employment, sustaining economic growth. Through its commitments on the UN Sustainability Goal 2 and Vision 2030, the government has pledged to increase food production.

\subsection{Statement of the Problem}

Performance of manufacturing firms in terms of contribution to GDP has been declining from 11.8\% in 2011 to 8.4 in 2017 (KAM, 2018). Indeed, production volumes have been contracting leading to an overall decline of 1.1 per cent in 2017 (KNBS, 2018). In terms of growth rate, performance has declined from $5.6 \%$ in 2013 to $0.2 \%$ in 2017. This decline has largely been attributed inferior 
performance of firms in the food manufacturing sector which declined by 10.8 per cent in 2017 (KNBS, 2018). Due to frequent shortages in the country, there has been increasing pressure on food manufacturing firms to increase performance and meet demand for food. Furthermore, globally, strategies are being sought to make firms better performing and more competitive (Easterby-Smith \& Prieto, 2008). There is however limited number of studies on how the interaction of dynamic capabilities and performance of firms in this sector to inform initiatives to stimulate growth in firms in this sector.

Research on sustainable performance suffers from gaps such as lack of consensus on its definition and selection of indicators (Combs, Crook, \& Shook, 2005) furthermore, many studies have measured sustainable performance with a single indicator (mainly financial performance and represented the concept as unidimensional, (Glick, Washburn, \& Miller, 2005). As such, the strategic management field clearly needs more studies so as to get a clearer conceptualization of sustainable performance and identify better measurement efforts (Richard, Devinney, Yip, \& Johnson, 2009). Furthermore, studies on the performance of manufacturing firms in Kenya have not considered the influence of dynamic capabilities on performance in the context of food processing firms.

Ambrosini and Bowman (2009) state that the role of dynamic capabilities is to impact on the firm's extant resource base and transform it in such a way that a new bundle or configuration of resources is created so that the firm can sustain or enhance its performance. Scholars have portrayed Dynamic Capabilities as direct drivers, preconditions, moderators, or mediators of sustainable performance (Arend and Bromiley, 2009).Thus, there is no consensus as to how the two are linked. Moreover, studies on how Dynamic Capabilities affect sustainable performance of Food manufacturing firms in Kenya are rare. Furthermore, the dynamic capabilities concept itself has not been exhaustively studied (Arend \& Bromiley 2009).

\subsection{Objectives of the Study}

The general objective of this study was to investigate the effect of dynamic capabilities on performance of food manufacturing firms in Kenya. Specifically, the study sought to assess the effect of adaptive capabilities on performance of food manufacturing firms in Kenya, determine the influence of marketing capabilities on sustainable performance of food manufacturing firms in Kenya; establish the effect of alliancing capabilities on sustainable performance of food manufacturing firms in Kenya; examine the effect of managerial capabilities on sustainable performance of food manufacturing firms in Kenya.

\subsection{Significance of the Study}

This study was significant in several ways. First, the overall findings of the study helps in informing policy decisions on how to mitigate food security in the country through using dynamic capabilities to enhance performance of food manufacturing firms. Secondly, the study provides managers of food manufacturing firms with additional information on how dynamic capabilities interact among themselves to influence performance. Third, the findings of the study are useful in informing investment decisions of potential entrepreneurs who wish to invest in food manufacturing ventures. Fourth, this study contributed to the existing body knowledge by showing how dynamic capabilities interact with other organizational variables such as firm competence to impact performance. Fifth, the study provides useful insights to future scholars who want to study dynamic capabilities.

\section{LITERATURE REVIEW}

\subsection{Theoretical Review}

This study was informed by the dynamic capabilities theory as the main theory. This theory was complemented by the theory of optimal firm size, the Upper Echelons Theory, the Balanced Score Card theory and the RBV theory. These theories were considered as relevant in illuminating the objectives and variables of the study.

\subsubsection{The Upper Echelons Theory}

Hambrick and Mason (1984), were the first proponents of the theory. According to this theory, managerial background characteristics predict strategic choices and performance levels. According to Hambrick (2007), the dominant principle of the theory is that managers' interpretations of the 
situations they face is motivated by their experiences, values, and personalities. This in turn affects the decisions they make. The theory posits that the performance of a firm depends on the characteristics of its managers such as age, functional background, and educational experiences (Sadeghinejad \& Najmaei 2013) in this vein, organizational outcomes depend at least in part, on TMT composition. They argue that by examining the individual characteristics of members of the TMT, insights into the manner by which individual interpretations of situational factors impact the decisions made by these employees can be gained as they relate to decision making and organizational performance (Adner \& Helfat, 2003). Tripsas and Gavetti (2000) highlight that senior managers determine the way Dynamic Capabilities are deployed.

The Upper echelons theory was considered to have considerable relevance in this study as it explains one of the reasons why different firms perform differently. The study therefore anchored the hypotheses relating to effect of managerial capabilities on performance.

\subsubsection{Resource Based View (RBV)}

The RBV was suggested by Wernerfelt (1984) and popularized by Barney (1991) using insights provided by Penrose (1959). The RBV presents a connection between internal resources, strategy, and the performance of the organization (Torrington, Hall and Taylor 2005). RBV was a shift from earlier suggestions that superior performance comes from managing factors that are external to the firm (Peteraf \& Bergen 2003). In essence the underlying presumption of theory is that it is the resources and competencies inherent in the firm rather than in the environment which determines sustainable performance (Wang Senaratne, \& Rafig 2015).According to Peteraf and Bergen (2003), a central premise of the resource-based view is that firms compete on the basis of their resources and capabilities.

The theory was considered relevant for this study as it emphasizes that value creation and superior performance of a firm is affected by combination of the competitive strategy and its resource base as posited by (Eisenhardt \& Martin, 2000). It explains how a form can increase performance by acquiring and utilizing VRIN resources and was therefore used to inform the independent variables

\subsubsection{Balanced Score Card Framework}

The Balanced Scorecard Framework was developed by Robert Kaplan and David Norton in 1992 as a framework for measuring performance from four different perspectives; financial, customer, internal process and learning and growth. According to Kaplan (2010), non-financial perspectives for measuring company success were introduced in the BSC framework because financial metrics were deemed not to offer an insufficient measurement of Performance. Couturier and Sklavounos (2019) and Drury (2004) argue that the need to integrate financial and non-financial measures of performance led to the emergence of the BSC as a set of performance measures drawn from the firm's strategy to give top management a comprehensive view of the performance organizational units. The framework is said to provide managers with a concise insight into the overall firm and therefore aids them to make informed decisions about objectives and overall performance (Bose \& Thomas, 2007).

According to Bisbe and Barrubés (2012) the BSC arms management with a flexible performance management tool that enables them to interpret, negotiate, modify, combine, and configure existing routines to suit local conditions. The BSC framework is relevant for this study as it was considered to be a useful mechanism for developing and selecting relevant performance indicators. The BSC framework was used to inform the dependent variable.

\subsubsection{Dynamic Capabilities Theory}

According Ambrosini and Bowman (2009), Terence's (1990) working paper is probably the first contribution developing the notion of dynamic capabilities. Dynamic capabilities theory itself was developed by Teece in 1994. Teece, Pisano and Shuen (1997,) saw competitive advantage in turbulent environments as a function of dynamic capabilities rather than competitive positioning or industry conflict. The theory enhances the RBV (Teece, Pisano\& Shuen, 1997; Teece 2017; Zahra et.al., 2006). Dynamic Capabilities theory explains long-run firm survival by showing how firms can manage competitive threats by redeploying their resources (Teece, 2010).

In this theory, sustainable performance depends on distinct processes shaped by asset positions and the evolution path(s) the firm has adopted or inherited (Teece \& Pisano, 2016). The theory suggests 
that Performance a firm during periods of rapid change depends on its ability to sharpen its technological, organizational, and managerial processes (Teece, 2017). Firms use Dynamic Capabilities to reconfigure their resources as markets emerge, collide, mutate, or cease (Eikelenboom, \& Jong, 2017).

According to Teece (2018), Helfat \&Peteraf, (2009) the price system is inefficient in allocation of a firm's resources. Therefore, managers give directives to deploy in value-enhancing ways. Because managers make decisions under uncertainty, they do not create once-and for-all solutions but continually reconfigure firm resources and competences as needed (Zara et.al. 2006). Teece (2014) argues that in this framework, sustainable performance comes from shappening internal processes, structures and procedures to generate innovations, be they technological or organizational. The Theory contributes to strategic management by explaining how firms can sustain performance using dynamic capabilities. This study used the Dynamic Capabilities Theory to inform the independent variable.

\subsection{Empirical Review}

A study was conducted by (Cabral 2014) to test whether differences adaptive capability is related to performance of firms in Brazil. The study used content analysis of literature instead of primary information collected directly from firms in Brazil. The results of data analysis using multiple linear regression showed that the effect of adaptive capabilities Performance is mediated by innovation strategy. The significance of the study was that it confirmed the view held by (Eisenhardt \& Martin 2000) that adaptive capabilities affect performance indirectly. The main limitation was that it did not consider non-financial indicators of performance.

Morgan, Vorhies and Mason (2009), conducted a study to examine the effect of marketing capabilities on firm Performance. The study collected primary data using questionnaires administered via a mail survey on 748 U.S. firms. Marketing capability was operationalized in terms of product development, pricing, channel management, marketing communications, selling, market planning, and marketing implementation while performance was operationalized in terms of profitability and market share. The study used structural equation modelling (SEM) technique to analyze the data. The findings indicated that market orientation and marketing capabilities are complementary assets that directly contribute to sustainable performance. The main limitation of the study was that study used data collected from USA, a cultural setting which the researchers argued led to a stronger market orientation-sustainable performance relationship.

Phapruke, Intakhan, and Nantana (2010) examined the effect of alliance capability on Performance. Alliance capability was operationalized in terms of business excellence and performance was operationalized in terms of firm growth. Data was collected using a questionnaire administered on a sample of 812 SMEs in Thailand. Data was analyzed using multiple regression technique. The study used Baron and Kenny (1986) model to test for mediation. The results showed that alliance capability mediates the relationship between knowledge transfer achieved through alliances and Performance. It also found that knowledge transfers in turn impacts Performance through innovation.

Kabongo and Boiral (2017) studied effect of managerial capability on Performance of eco-efficient firms. Primary data was collected from managers of 12 firms involved in processing of waste materials in Canada using questionnaires and interviews. The findings of multiple regression showed that Performance of eco efficient firms largely depends on application of managerial capabilities in coordination of competencies, innovation and technological development. It also depends on adjustments in human resource management, networking and marketing. This study contributed to existing literature on Dynamic Capabilities by offering additional insights on the role played by management capability in the success of firms.

\subsection{Conceptual Framework}

The study proposed a conceptual model where it was hypothesized that dynamic capabilities affect the performance of food manufacturing firms. Based on theoretical models found in the literature review the conceptual framework shown in Table 2 was adopted.

In the framework, dynamic capabilities were operationalise in terms of adaptive, marketing, alliancing and managerial capabilities. The study framed the following hypotheses: 
Hypothesis one: Adaptive capabilities have no significant effect on performance of food manufacturing firms in Kenya

Hypothesis two: Marketing capabilities have no significant effect on performance of food manufacturing firms in Kenya.

Hypothesis three: Alliancing capabilities have no significant effect on performance of food manufacturing firms in Kenya.

Hypothesis four: Managerial capabilities have no significant effect on performance of food manufacturing firms in Kenya

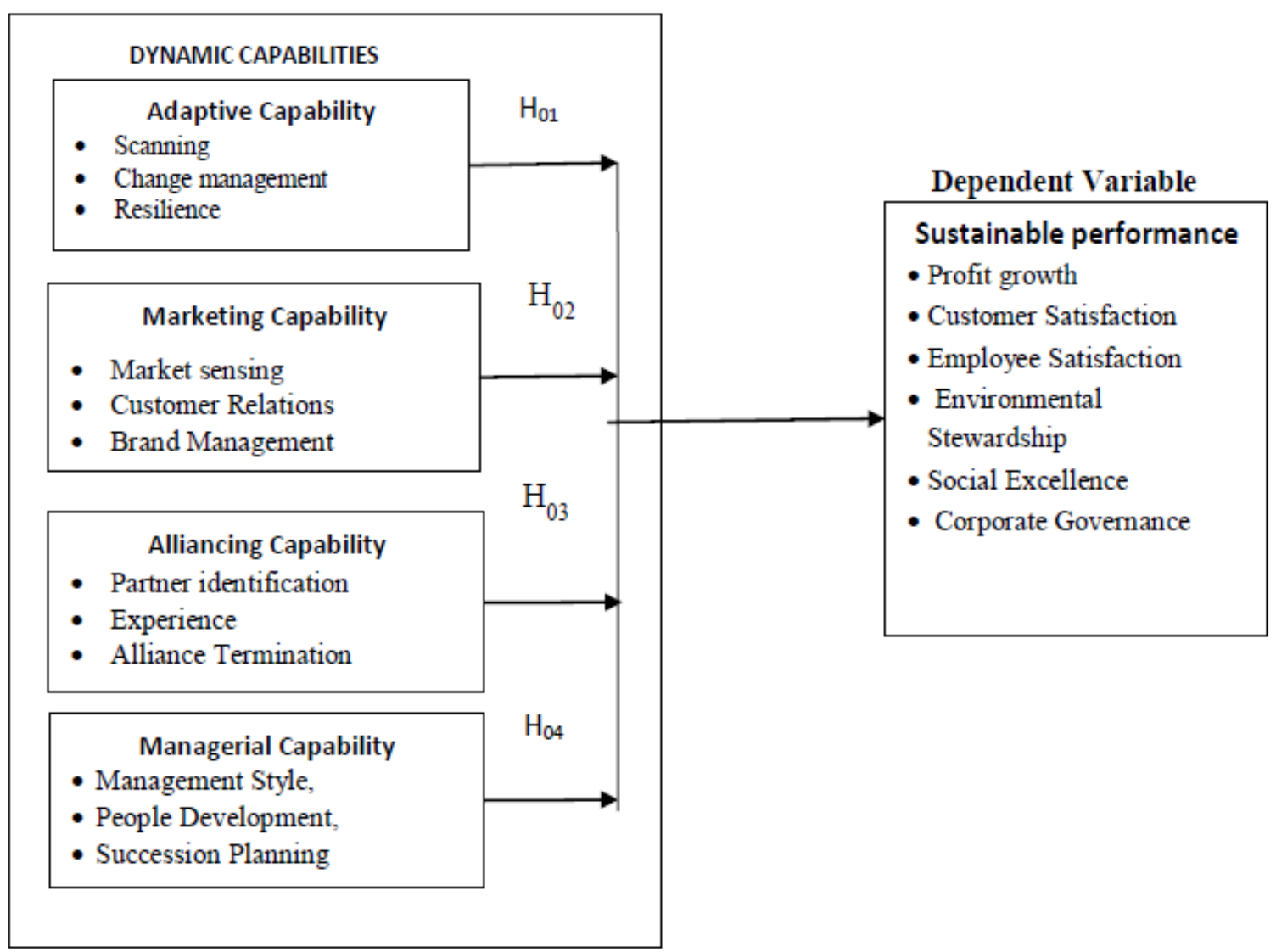

Figure1: Conceptual Framework

Source: Author, (2019)

\section{Methodology}

\subsection{Research Philosophy and Design}

This study inclined to positivistic view in order to obtain an objective view of the relationship between dynamic capabilities, and performance of selected food manufacturing firms in Kenya. Based on the purpose of the study and the philosophical orientation adopted, the study used a descriptive, explanatory and cross-sectional survey research design. This design was chosen because it is convenient and saves the researcher time and costs associated with longitudinal studies which involve taking multiple measures over an extended period.

\subsection{Empirical Model}

To test for direct relationship between dynamic capabilities and performance was tested using multiple regression analysis. Objectives one through four were addressed using model 3.1 below

$$
\mathrm{Y}=\boldsymbol{\beta}_{0}+\boldsymbol{\beta}_{1} \mathrm{AC}+\boldsymbol{\beta}_{2} \mathrm{MC}+\boldsymbol{\beta}_{3} \mathrm{LC}+\boldsymbol{\beta}_{4} \mathrm{GC}_{+}
$$

Where: $\mathrm{Y}=$ Performance (dependent Variable), $\boldsymbol{\beta}_{\mathrm{i}}=$ Beta coefficients $(\mathrm{i}=0,1,2,3,4), \mathrm{AC}=$ Adaptive Capability, $\mathrm{MC}=$ Marketing Capability, $\mathrm{LC}=$ Alliancing Capability, $\mathrm{GC}_{4}=$ Managerial Capability, $\varepsilon=$ Error term 
The coefficients measured the effect of the independent variables (AC, MC, LC, and GC) on the dependent variable Y.

\subsection{Target Population and Sample Size}

The target population consisted of 70 food manufacturing firms operating in Nairobi county Kenya and listed in the directory of manufacturers published by the Kenya Association of manufacturers as at June 2018. This study adopted the simplified sampling method developed by Krejcie and Morgan (1970) for determination sample size for a finite population. According to Krejcie and Morgan (1970) the formula for determining a sample size for a finite population is as follows;

$$
\frac{s=\mathrm{X}^{2} N P(1-P)}{d^{2}(N-1)+\mathrm{X}^{2} P(1-P)}
$$

Where; $s=$ sample size needed. $X^{2}=$ confidence level desired (3.841). $N=$ population size.

$P=$ the population proportion, $\mathrm{d}=$ the degree of accuracy.

Using this model, it was determined that a sample of 59 Firms would suffice for a population of 70 . The 59 firms were chosen using a ratio of $84 \%$ from each category to represent the entire population. From these 59 firms, 5 respondents were identified from each of the firms. This sample size of 295 was considered adequate based on (Creswell and Plano 2011) proposition that a sample of at least 30 must exist for generalization to take place.

\subsection{Data Collection and Instrumentation}

Primary data was collected on dynamic capabilities and performance indicators using semi-structured questionnaire. The instrument was adopted from strategic management studies that have studied similar variables with modifications aimed at addressing the specific objectives. Closed-ended questions were constructed on a 5-point Likert Scale to provide structured responses to facilitate quantitative analysis, testing of hypotheses and drawing of conclusion. However, open-ended questions were used to enable respondents provide additional information that would not be captured in the closed-ended questions. This method was preferred because of the need to ensure reliability of responses from the respondents. The semi structured questionnaires were administered to senior managers responsible for Finance, Marketing, Human Resources and Corporate affairs in each of the firms. These functional heads were presumed to be knowledgeable in the areas under study.

A pilot study was also undertaken to help in establishing the degree of clarity of the proposed research instruments and also help identify issues in the research design that needed to be addressed prior the main study (Zikmund, 2003) .The pilot study was conducted among 20 non-food manufacturing firms located in another county other than Nairobi where the study was being conducted.

\section{DATA ANALYSiS}

\subsection{Reliability of Research Instrument}

The overall Cronbach's Alpha as per pilot study was 0.91. The Cronbach's alpha coefficient rages from 0 to 1 . According to Cooper and Schindler (2003), while a minimum threshold of 0.70 is recommended for exploratory work, a Cronbach's Alpha value above 0.50 is regarded as an indicator of reliability. In this study, the threshold for Cronbach's Alpha of the research instruments was set at $\alpha=0.6$ where variables with $\alpha$ greater than 0.6 were considered to have internal consistency or reliable. The results indicate that all the variables attained a Cronbach's above the acceptable level of 0.60.thus the research questionnaire was found to be reliable.

\subsection{Analysis of Response Rate}

Out of the 295 distributed, 190 were returned representing a response rate of $64.4 \%$. According to Wimmer and Dominick (2006), a response rate of $21 \%$ - $70 \%$ is acceptable for self-administered questionnaires. The overall response rate of $64.4 \%$ was therefore considered to be satisfactory for the analysis and reporting. Unreturned questionnaires were attributed to factors such as busy schedules of the respondents since majority most of targeted respondents were senior managers in their respective firms 


\subsection{Characteristics of Respondents}

A summary of Respondents Characteristics is set out in Table 1

Table1: Characteristics of respondents

\begin{tabular}{|l|l|l|}
\hline \multicolumn{1}{|c|}{ Gender } & Frequency & Percent \\
\hline Male & 121 & 63.7 \\
\hline Female & 69 & 36.3 \\
\hline Total & 190 & 100 \\
\hline Years of service in organization & & \\
\hline 1-3 years & 26 & 13.7 \\
\hline 4-5 years & 56 & 29.5 \\
\hline more than 5 years & 108 & 56.8 \\
\hline Total & 190 & 100 \\
\hline Core Business of respondents firm & & \\
\hline Beverage Manufacturing & 44 & 23.2 \\
\hline Flour Milling & 37 & 19.5 \\
\hline Sugar Confectionery & 24 & 12.6 \\
\hline Meat \& Fish Processing & 23 & 12.1 \\
\hline Dairy Processing & 23 & 12.1 \\
\hline Edible Oil Refining & 16 & 8.4 \\
\hline Bread and Pastry & 11 & 5.8 \\
\hline Spice and Condiments & 8 & 4.2 \\
\hline Honey Processing & 4 & 2.1 \\
\hline Total & 190 & 100.0 \\
\hline
\end{tabular}

Source: Survey data 2019

\subsection{Descriptive Statistics}

The respondents were asked to respond to statements on each of the variables on a scale of 1-5. Where $1=$ "not at all, " $2=$ "slight extent" $3=$ "moderate extent" $4=$ "high extent" and 5 = "very high extent". Measures of central tendency specifically the mean and standard deviation were used to summarize the characteristics of the variables under study. A summary of the Descriptive statistics were as shown in Table I below.

Table1: Descriptive Statistics

\begin{tabular}{|l|l|l|}
\hline \multicolumn{1}{|c|}{ Variable } & Variable Aggregate & \multicolumn{1}{c|}{ Std Deviation } \\
\hline Adaptive capability & 3.96 & 1.250 \\
\hline Marketing capability & 3.69 & 1.250 \\
\hline Alliancing capability & 3.50 & 1.334 \\
\hline Managerial capability & 3.33 & 1.344 \\
\hline Performance & 3.55 & 1.083 \\
\hline
\end{tabular}

Source: survey data: 2019

\subsection{Diagnostic Tests}

To test for normality assumptions, this study utilized the Shapiro-Wilk test to test for normality. Levene's test for equality for variances was used to determine the existence of Heteroskedasticity. Multicollinearity was diagnosed using variance inflation factor (VIF) techniques.

Garson, (2012) suggests that Wilk's test should not be significant if the assumption of normality is met. All the variables had a P-value greater than 0.05 . The results showed that all the variables had Levene statistics with p-value greater than 0.05 . Consequently, the study failed to reject the null hypothesis that the data was homoscedastic .According to Field (2009), VIF values greater than 10 or Tolerance values below 0.1 indicate high levels of multicollinearity problem. The study therefore set a threshold of $(\mathrm{VIF}<10)$ and Tolerance value of $(\mathrm{T} \geq 0.01)$ to interpret that there is no problem of multicollinearity. The results showed that there was no threat of multicollinearity since all the variables had VIF of less than 10. Similarly, all the variables had a Tolerance value of more than 0.1.

\subsection{Research Findings}

Multiple regression analysis was conducted at 95 percent confidence level $(\alpha=0.05)$ 
Table3: Relationship between Dynamic Capabilities and sustainable performance

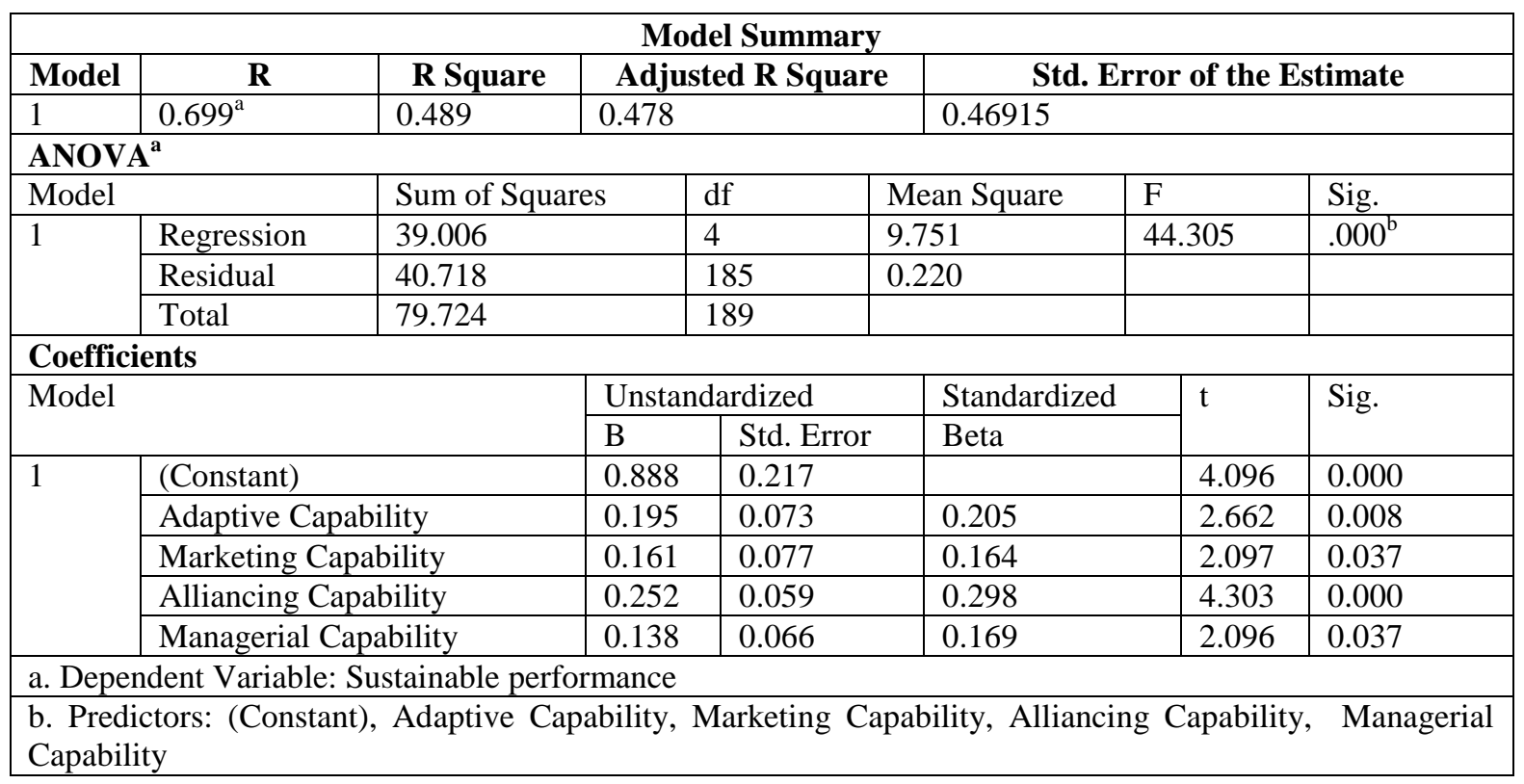

Source: Survey Data, (2019)

The model fitted had an Adjusted R Square $=0.489$ which show that dynamic capabilities (adaptive capability, marketing capability, alliancing capability and managerial capability) explained $48.9 \%$ of the variation in firm's performance. The remaining $51.1 \%$ was explained by other variables other than the ones in the model. These findings showed that dynamic capabilities are significant predictor variables of sustainable performance. The findings agreed with Ambrosini and Bowman (2009), Easterby-Smith and Prieto (2008) and Teece, (2008) who found that dynamic capabilities significantly enhance sustainable performance.

The ANOVA results showed $F(4,189)=44.305$ (which is greater than critical $F$ value of 2.42 ) and pvalue $<0.001$ (which was less than 0.05 .) The study therefore failed to reject the null hypothesis that the model fitted had a goodness of fit. These results found that dynamic capabilities significantly explained performance of food manufacturing firms in Kenya and the model was statistically significant and adequate to predict performance.

The Beta coefficients showed that all the independent variables had a significant effect on the dependent variable. Adaptive capability had $\beta=0.205$, P-0.008). Marketing capability $\beta=0.164$, $\mathrm{P}=0.037$ Alliancing capability had $\beta 0.298, \mathrm{P}=0.000$ Managerial Capability $\beta=0.169 \mathrm{P}=0.037$ ). Based on the results of the regression analysis the regression model was estimated in the equation below as follows:

\section{$\mathrm{Y}=0.888+0.205 \mathrm{AC}+0.164 \mathrm{MC}+0.298 \mathrm{LC}+0.169 \mathrm{GC}+\varepsilon$}

\section{DISCUSSIONS AND IMPLICATIONS FOR THEORY}

The first objective of the study was to determine the effect of adaptive capabilities on performance. The results of multiple regression in showed that adaptive capabilities had $\beta_{1}=0.205$, $\mathrm{p}$-value $=0.008$. Since $\beta_{1} \neq 0$ and $p$ was less than the significant level of 0.05 , the study rejected $\mathrm{H}_{01}$ implying that adaptive capabilities have a positive and significant effect on the performance of food manufacturing firms in Kenya. The conclusion drawn was that adaptive capability has a significant and positive effect on performance of food manufacturing firms.

Adaptive capability by their nature helps firms to reconfigure their resources so as to adapt to the changing business environment. In this way, firms obtain a viable fit with their external environment so that the organization responds to emerging business opportunities. Responding to business opportunities means that the firm is able to continually sell its products and raise revenue. In considering the financial aspect of performance, the descriptive statistics indicated that the firms on average registered a positive growth of between 1- 10\% implying that there was increase in sales, profits and marker share. Thus, it is possible to show how adaptive capabilities developed by the sample firms contributed to a positive performance of food manufacturing firms in Kenya. 
The real-life practice of strategic management in organizations assigns the strategic management practices associated with adaptive capabilities to the top echelon of the organization mostly corporate and business levels. In considering the demographic characteristics of the profiles of respondents of the study, it was observed that $94.7 \%$ of the respondents had over 6 years of work experience in firms that had existed in the industry for the same period of six years. Thus, given this kind of experience in doing planning and executing strategic management practices for survival in the same environment the characteristics of the respondents justifies the significant effect of dynamic capability on the performance of food manufacturing firms in Kenya.

In addition, the dimensions of adaptive capability used in this study were measured through horizon scanning, change management and resilience. The findings in the descriptive section showed that they were rated in this study at high extent. The study singles out the roles of scanning and effecting required changes to build business resilience suitable to sustain the business. The theoretical literature on dynamic capabilities provide a highly valuable contribution towards sustainable performance in that they offer the needed flexibility for dealing with environmental complexity in a rapidly changing environment.

The results of analysis of descriptive data showed that the respondents' firms had committed to creating of adaptive capabilities in the form of horizon scanning Change Management and resilience. The current study showed that top management in organizations use horizon scanning to detect early signs of potentially important developments through a systematic examination of potential threats and opportunities, new technologies and their effects on the business Horizon scanning provides the background to develop strategies for anticipating future developments and thereby gain lead time It also provides a way to assess trends to feed into a scenario development process. It provides background for review of products strategies to enable food manufacturing firms to build resilience to respond to business disruptions.

The current study followed the direction previously set by Cabral (2010), Kaehler, Busatto, Grace, Hansen and Santos (2014), Eshima and Anderson (2016) and Ali, Sun and Ali (2017). The studies had focused on the relationship between adaptive capabilities and business performance and found that adaptive capabilities positively influence performance. The findings of this study favorably compare with those of the previous studies in that they demonstrate direct and positive influence effect of adaptive capabilities on sustainable performance. Studies by Eisenhardt and Martin (2000), and Protogerou, Caloghirou and Lioukas (2011) however reported that adaptive capabilities indirectly influence sustainable performance.

The second objective of the study was to determine the effect of marketing capabilities on the performance of food manufacturing firms in Kenya. The study therefore tested the hypothesis that marketing capabilities have no significant effect on performance of food manufacturing firms in Kenya. The decision criteria was to fail to reject $\mathrm{H}_{02}$ if, $\beta_{1}=0$ and $\mathrm{P}>0.05$. The results showed that marketing capabilities had $\beta_{2}=0.164$, $\mathrm{p}$-value $=0.037$. Since $\beta_{2} \neq 0$ and $\mathrm{p}$ was less than $0.05, \mathrm{H}_{02}$ was rejected and the alternative hypothesis was taken to hold implying that marketing capabilities have a significant effect on performance of food manufacturing firms in Kenya. The results demonstrated marketing capabilities enhanced sustainable performance. The study therefore concluded that marketing capabilities have a positive and significant effect on performance of food manufacturing firms in Kenya.

These findings were explained in terms of the dynamic capabilities theory, descriptive characteristics and previous studies on the variable. A basic concept in marketing is that to achieve success, firms must use marketing capabilities to position their products the marketplace in such a way that consumers believe they need their products and that those products have a particular benefit. In practice a firm's marketing strategy is designed by top management and works within the direction provided by the overall corporate strategy. They interact with other elements of the corporate strategy and define how the company will use marketing capabilities to target, position, and market and sell its products.

In strategic management, the principal idea behind the concept of a strategic window is that there are only limited periods during which the link between the key requirements of a market and the particular competencies of a firm competing in that market is at an optimum. Consequently, investment in new product lines or a market area is timed to coincide with periods during which a 
strategic window is open. Scholars have argued that to attain long term success, firms develop marketing capabilities that enable them to collect information about market opportunities, develop goods and services to meet the needs of customers in selected markets and to price these products according to market information.

Conceptually, Market sensing capabilities enable firms to sense and react to market changes and facilitate firms to foretell and anticipate customer explicit and latent needs. These, in turn, help them to develop new products or employ existing products with new features and attributes to satisfy both the needs of current customers and new customers to ensure the stability and survivability. In this regard, findings from descriptive statistics showed that food manufacturing firms, to a moderate extent use market sensing capabilities to scan the environment for strategic windows and threats through expending resources on market research and monitoring of market trends.

Managing customer relationships is a key aspect of marketing which is in turn a building block for firm success. Firms use customer relationship management capabilities to persuade the ultimate consumers to buy their products and persuade others that what it sells meets their needs. Customer relationship management capabilities help firms to communicate product advantages to potential customers and distribute products to customers. In this regard, the descriptive statistics results of the current study have shown that to a moderate extent, food manufacturing apply their collective knowledge, skills, and resources to the market-related needs, thus enabling them to add value to their customers and be competitive.

Another key component of marketing in food manufacturing firms is competitive positioning of products in the minds of the customers. Because of its dependence of communication, marketing demands a discriminating brand name or trademark to identify the products. The results of descriptive statistics showed that to a large extent, firms use brand management capabilities to create customer loyalty, persuade the new buyers, and establish an emotional connectivity with the customers and influence consumers perception and attitude toward their brands.

Considering the demographic characteristics of the respondent firms, it was observed that $43 \%$ of the respondents had an annual sales turnover of over Ksh 50 million in terms of market share, $71.1 \%$ of the respondents' firms held a market share below 20\%. Most of the respondents indicated that their firms did not provide adequate budgets for market research and branding activities and this may explain the large number of firms with small market share.

The findings of the current study are compared with previous studies done by Morgan, Slotegraaf and Vorhies (2009); Azizi, Movahed and Khah, (2009); Vijande, Pérez, Gutiérrez and Rodriguez, (2012) and Morgan, Vorhies and Mason, (2009). These studies focused on the effect of marketing capability on performance and reported that marketing capabilities have a direct effect on sustainable performance. The current study agrees with these studies to the extent that marketing capabilities have a positive and direct effect on performance. The findings contradict those of Afzal. (2009) that marketing capabilities have a moderating effect on sustainable performance.

The third objective was to determine the effect of alliancing capability on performance. The results showed that alliancing capabilities had $\beta_{3}=0.298$ and $p$-value $<0.001$. Since $\beta_{3} \neq 0$ and $p$ was less than $0.05, \mathrm{H}_{03}$ was rejected and the alternative hypothesis accepted implying that alliancing capabilities have a significant effect on performance of food manufacturing firms in Kenya. The study therefore concluded that alliancing capabilities have a significant and positive effect on sustainable performance of food manufacturing firms in Kenya. These findings were explained by the conceptual nature of the variable, the RBV theory, the Dynamic capabilities theory, and the demographic data on the variable, descriptive statistics and previous studies.

Conceptually, alliancing is a corporate strategy where firms interact with partial congruence of interests whereby they cooperate with each other to reach a higher value creation if compared to the value created without interaction and compete separately to increase their market share. They are used to develop a collection of value-creating resources that a firm cannot create independently. Few food manufacturing firms in Kenya have all of the resources needed to compete effectively in the current dynamic landscape. Thus, firms seek access to the necessary resources through alliances. As articulated by Anand and Khanna, (2000) it is a firm's alliance capabilities that influence the ability of firms to create and capture value, through alliances. In line with the RBV, alliancing capabilities are 
an intangible asset which food manufacturers can use to influence the operating environment and thus enhance performance through reduction of external cost of doing business.

This study conceptualized alliancing capabilities in terms of alliance experience, interorganizational coordination, and partner identification propensity. Alliancing capabilities enhance sustainable performance of firms by enabling them to overcome resource constraints, enter new markets and hedge against environmental uncertainties and even create options to expand. The study found that food manufacturing firms in Kenya have, to a large extend used alliance experience to lobby for favorable government regulations, jointly fight counterfeit, setting industry standards, negotiate for favorable tax regimes and to share information about industry trends.

Regarding interorganizational coordination, the study found that food manufacturing firms encourage their managers to participate in leadership of industry associations. The descriptive statistics also showed that the respondent firms have managers responsible for intra industry partnerships and they frequent review their alliance portfolios. This coordination supports sustainable performance through endorsement and recognition by peers and builds reputation for the firms and their brands. Trust by peers and customers explain why most of the firms have been resilient for more than 10 years since inception.

On partner identification propensity, the study found that food manufacturing firms use alliance capabilities to identify potential partners, initiate and termination relationships all the firms were members of an industry association and were constantly looking for partners. The firms also indicated that they had created partnerships with farmers and suppliers to secure stability of prices and raw material.

This study followed the direction set by Rotharmel and Deeds (2006); Schreiner, Kale, and Corsten, (2009); Phapruke, Intakhan and Nantana, (2010) and Ziggers and Tjemkes (2010). These studies focused on the role of alliancing capabilities on performance and reported that showed that firms capable of deploying their alliance capability in the entire alliance process gain better results from their alliances. The findings on this variable agree with these other studies to the extent that they showed that a firm's performance is positively correlated to its alliance capability.

The fourth objective was to examine the effect of managerial capability on the performance of food manufacturing firms in Kenya, The study therefore tested $\mathrm{H}_{04}$ that managerial capabilities have no significant effect on performance of food manufacturing firms in Kenya. The decision criteria was to fail to reject $\mathrm{H}_{04}$ if $\beta_{4}=0$, and $p$-value was more than 0.05 . The results of multiple regression showed that managerial capabilities had $\beta_{4}=0.169, \mathrm{p}$-value $=0.037$. Since $\beta_{4}=0$ and $\mathrm{p}$-value was less than 0.05. $\beta=0\left(\mathrm{H}_{04}\right)$ was rejected and the alternative hypothesis $\beta_{4} \neq 0$ was accepted implying that managerial capabilities positively and significantly affected performance of food manufacturing firms in Kenya. The study therefore concluded that managerial capabilities have a strong and positive effect on the performance of food processing firms.

These findings were explained by the conceptual nature of the variable, upper echelons theory, cognitive theory, and demographic characteristics of the respondents, descriptive data and previous studies on the variable. Fredrickson (2001) states that because it is not possible for all managerial characteristics needed in an organization to reside in one person no matter how talented, firms rely on the collective knowledge and capabilities residing in top management teams to deliver performance. As pointed out by Penrose (1959), a firm's repository of proprietary firm specific knowledge held by its managers determines the speed at which a firm can take advantage of emerging opportunities in its domain of business.

In line with the cognitive theory of the firm, knowledge structures residing in top management teams are employed as mental templates for decision making. As indicated by Helfat and Raubitschek (2000) managers have perceptions and knowledge of the firm's resources, its business environment, its customer base and its competitive challenges. The demographic characteristics showed that $86.3 \%$ of the respondent managers had worked in the same firm for more than 4 years. Based on previous experiments, accomplishments, and failures during this period managers have developed these cognitive lenses through which they perceive and interpret the world.

The current study conceptualized managerial capabilities in terms of management style, people development, managerial human capital and succession planning. The descriptive statistics on the 
variable showed that management of food manufacturing firms had built managerial capabilities in human capital management style people development and succession planning) the results also showed that the firms had employed line managers with functional experience to enable them to efficiently perform their tasks. The study results also showed that firms had encouraged their managers to create social capital through social ties such as friendships social club memberships, directorships of other companies and transfer the goodwill and knowledge that these lies confer to their influence to work settings.

This study followed the direction of Tripsas and Gavetti (2000), Adner and Helfat (2003), Eggers and Kaplan, (2009), Bellner and MacLean, (2015), Kabongo and Boiral, (2017), Ali, Sun, and Ali (2017). Kor and Mesko, (2009) Ahmed, (2017). These studies focused on the effect of managerial capabilities on performance and reported that performance in firms depends on the application of managerial capabilities. The findings of the current study agree with these previous studies that managerial capability directly affects sustainable performance.

\section{CONTRIbUtion OF THE STUdY TO KNOWLEDGE}

One of the ongoing discourses in strategic management is why some firms perform better than others. At the centre of this discourse is the question of whether a firm's dynamic capabilities is related to its performance. Past empirical studies have portrayed dynamic capabilities as predictors, of sustainable performance while others have portrayed them as moderators and mediators of the relationship between performance and other variable. Furthermore, previous studies on the relationship between dynamic capabilities in Kenya have used only financial indicators of performance leaving out the nonfinancial indicators.

This study contributes to the general body of knowledge in several ways. First, it contributes the ongoing discourse on why some firms perform better than others by empirically testing the effect of dynamic capabilities on performance of food manufacturing firms in Kenya, This study establishes empirically that dynamic capabilities positively and significantly influence the performance of manufacturing firms. Second, the study it provides more understanding on the role of adaptive by showing that adaptive capabilities have a positive and significant effect on performance.

\section{AREAS FOR FURTHER RESEARCH}

This study recommends several areas of further research. First, the study showed that adaptive capability, marketing capability, alliancing capability and managerial capability explained $44.4 \%$ of the variation in performance food manufacturing firms in Kenya. The study recommends that further studies should focus in establishing other factors that account for the remaining $65.6 \%$ of the variation in performance of the food manufacturing firms in Kenya. Second, the study suggests that future studies on dynamic capabilities should also focus on other types of dynamic capabilities such as absorptive capabilities and innovative capabilities. Third, the study recommends further research on the effect of dynamic capabilities on the performance of organizations in the service sector in Kenya. In this regard, the study suggests further investigation of the effect of dynamic capabilities on the performance of firms in the tourist sector, and also public service departments.

\section{CONCLUSIONS AND RECOMMENDATIONS}

Based on the summary findings, several conclusions can be made. First, the findings of this study show that dynamic capabilities have a direct and positive effect on performance. Therefore, increasing dynamic capabilities can increase overall performance of food manufacturing firms. The study therefore makes a number of recommendations. First, management of food manufacturing firms should deliberately build dynamic capabilities to enable them to scan the environment for opportunities, threats and technologies that will inform their strategies on how to respond to market changes. Moreover, manufacturing firms should build resilience to enable them to survive and adversities and unforeseen changes in the market. Further, the study recommends that management of manufacturing firms create environment for employees to offer solution besides traditional strategies to effective respond to market disruptions.

Second, this study revealed that lack of adequate budget for market research limited firms from developing marketing capabilities and product development as informed by market research in majority of the firms surveyed. The study therefore recommends that management together with 
stakeholders should review the budget allocations set aside for development for marketing capabilities.

Third, the study found that food manufacturing firms only recruit managers who have functional skills. The study notes that in order to gain superiority, a firm requires that top management possesses a broad set of complementary skills however, it is unlikely that a single person no matter how talented, would possess all the managerial skills required for the successful operation of a large organization. The study therefore recommends that manufacturing firms should invest in strengthening of managerial capabilities of the entire top management teams before looking for top managers from outside the firm. Furthermore, firms should invest in building TMT's human and social capital. Fourth the study recommends that Government interventions aimed at increasing food security should institute policies aimed at helping food manufacturing firms to build dynamic capabilities.

The main limitation of this study was that it was conducted among food processing firms in Nairobi County, which hosts the capital city of Kenya. The results may therefore not be easily generalizable to firms in other sectors and other counties with different resource constrains and business operating challenges.

\section{REFERENCES}

[1] Adner, R. \& Helfat, C. E. (2003). Corporate effects and dynamic managerial capabilities. Strategic Management Journal, 24(10) 1011-1025.

[2] Afzal, S. (2009). Marketing Capability, Strategy and Business Performance in emerging markets of Pakistan IUB. Journal of Social Sciences and Humanities, Vol.7 No.2, 2009.

[3] Ahmad K.A. (2017)," The Influence of Development on Managerial Capabilities and Performance: Empirical Evidence from Pakistan", Journal of Southeast Asian Research, Vol. 2017 (2017), Article ID 164526, DOI: 10.5171/2017.164526

[4] Ali, Z., Sun, H. \& Ali, M. (2017). The Impact of Managerial and Adaptive Capabilities to Stimulate Organizational Innovation in SMEs: A Complementary PLS-SEM Approach. Sustainability (Switzerland). 9. 2157. DOI: $10.3390 / \mathrm{su} 9122157$

[5] Ambrosini, V. \& Bowman C. (2009), what are dynamic capabilities and are they a useful construct in strategic management, https://doi.org/10.1111/j.1468-2370.2008.00251

[6] Arend R.J \& Bromiley P. (2009) Assessing the dynamic capabilities view: spare change, everyone? Strategic Organization Vol 7 issue 1 pages 75-90 https://doi.org/10.1177/1476127008100132

[7] Azizi. S, Movahed M. \& Khah H. (2009). The effect of marketing strategy and marketing capability on business Performance. Case study: Iran's medical equipment sector, Journal of Medical Marketing Vol. 9, 4, 309-31

[8] Barney J (1991) Firm Resources and Sustained Competitive advantage Journal of Management 1991 Vol 17 No 1 pp. 99-120

[9] Bellner, B. \& MacLean, D. (2015) Dynamic Managerial Capabilities and Competitive Advantage Strategic Management Quarterly September 2015, Vol. 3, No. 3, pp. 1-23 ISSN: 2372-4951 (Print), 2372-496X (Online). Published by American Research Institute for Policy Development DOI: 10.15640/smq. V3n3al URL: http://dx.doi.org/10.15640/smq.v3n3al

[10] Bisbe, J., \&, Barrubés, J. (2012). The Balanced Scorecard as a Management Tool for Assessing and Monitoring Strategy Implementation in Health Care Organizations. Revista Española de Cardiología, 65(10), 919-927. https://doi.org/10.1016/j.recesp.2012.05.014

[11] Bose, S., \& Thomas, K. (2007). Applying the balanced scorecard for better performance of intellectual capital. Journal of Intellectual Capital, 8 (4), 653-665.

[12] Cabral, J. (2010). Inventions and sustainable innovations: the moderator effects of dynamic capabilities, technology characteristics and demand conditions. ResearchGate Conference Paper. The International Conference on Industrial Engineering and Operations Management, At São Carlos - SP, Volume: 1.

[13] Couturier J, Sklavounos N (2019) Performance dialogue: A framework to enhance the effectiveness of performance measurement systems. International Journal of Productivity and Performance Management ISSN: $1741-0401$

[14] Creswell, J. W. \& Plano C. (2011). Designing and conducting mixed method research (2ndEd.). Thousand Oaks, CA: Sage.

[15] Crook, T. \& Combs, James \& Shook, Christopher. (2005). the Dimensionality of Organizational Performance and its Implications for Strategic Management Research. In D.J. Ketchen \& D.D. Bergh (Eds.) Research Methodology in Strategy and Management. 2. 259-286. 10.1016/S1479-8387(05)02011-4. 
[16] Drury, C. (2004): Management and Cost Accounting (6th Ed.), London, Book Power

[17] Eikelenboom, M. \& Jong, D.G. (2017). The impact of Dynamic Capabilities on Performance: Theory and evidence from Dutch SMEs. Centre for Sustainable Entrepreneurship. University of Groningen/Campus Fryslân https://www.rug.nl/cf/cse/for-scholars/working-paper-series

[18] Eggers JP, Kaplan S. (2009). Cognition and renewal: Comparing CEO and organizational effects on incumbent adaptation to technical change. Organization Science 20(2): 461-477

[19] Eshima, Y. \& Anderson, B. (2016). Firm growth, adaptive capability, and entrepreneurial orientation: Research Notes and Commentaries. Strategic Management Journal. 38. 10.1002/smj.2532. https://www. researchgate.net/publication/303040720.

[20] Easterby-Smith, M P V; Prieto, I (2008).Dynamic capabilities and knowledge management: an integrative role for learning? British Journal of Management, Vol. 19, No. 3, 2008, p. 235-249

[21] Eisenhardt K. \& Martin, J.A. (2000) Dynamic Capabilities: What Are They? Strategic Management Journal. 21: 1105-1121 2000

[22] Glick, W.H., Washburn, N.T. and Miller, C.C. (2005) the Myth of Firm Performance. Proceedings of the Annual Meeting of American Academy of Management, Honolulu, 5-10 August 2005.

[23] GOK (2018); Economic survey, Nairobi, Kenya

[24] Hambrick, D.C \& Mason P.A. (1984) Upper Echelons: The Organization as a Reflection of Its Top Managers; Academy of Management Review Vol. 9, No. 2 https://doi.org/10.5465/amr.1984.4277628

[25] Hambrick, D.C (2007) Upper Echelons Theory: An Update Academy of Management Review Vol. 32, No. 2 https://doi.org/10.5465/amr.2007.24345254

[26] Helfat C E \&Peteraf, M.A. (2009): Understanding dynamic capabilities: progress along a developmental path. Strategic Organization Vol 7(1): 91-102

[27] Kabongo, J.D. \& Boiral, O. (2017). Doing More with Less: Building Dynamic Capabilities for EcoEfficiency. Business Strategy and the Environment. https://www.researchgate.net/publication/315914931

[28] Kaehler, C. B., Usato, F., Becker G, Hansen B, Lucia J (2014) Relationship between Adaptive Capability and Strategic Orientation: An Empirical Study in a Brazilian Company. IBusiness, 6, 1-9. http://dx.doi.org/ 10.4236/ib.2014.61001

[29] Kaplan, R.S., (2010) Conceptual Foundations of the Balanced Scorecard Harvard Business School Working Paper 10-074

[30] Kenya Association of Manufacturers (KAM) (2017), Manufacturing in Kenya, Challenges and Opportunities

[31] KNBS (2018) Economic survey 2018

[32] Kor, Y. Y., Mahoney, J. T., \& Michael, S. C. (2007). Resources, capabilities, and entrepreneurial perceptions. Journal of Management Studies, 44: 1187-1212.

[33] Morgan, N.A., Vorhies, D. \& Mason C. (2009). Market orientation, marketing capabilities, and firm performance Strategic Management Journal, 30: 909-920 (2009) Wiley InterScience (www.interscience. wiley.com) DOI: $10.1002 / \mathrm{smj} .764$

[34] Nair, A., Trendowski, J., \& Judge, B. (2008). The Theory of the Growth of the Firm, by Edith T. Penrose. Oxford: Blackwell, 1959 [book review].Academy of Management Review, 33(4), 1026-1028.

[35] Peteraf, M \& Bergen, M. (2003). Scanning Dynamic Competitive Landscapes: A Market-Based and Resource-Based Framework. Strategic Management Journal. 24. 1027 - 1041. 10.1002/smj.325.

[36] Phapruke, U., Phaithun I, \& Nantana, O. (2010) Effects of alliance experience, resource exchange and trust on competitive advantage and performance of government promoted investment firms in Thailand. International Journal of Business Strategy: Volume: 10 Issue: 1

[37] Protogerou, A., Caloghirou, Y.\& Lioukas, S. (2011) Dynamic Capabilities and Their Indirect Impact on Sustainable performance, DRUID Working Paper no. 08-11 JEL codes: ISBN: 978-87-7873-265-1

[38] Richard, P. Devinney, T, Yip, G. \& Johnson, G. (2009). Measuring Organizational Performance: Towards Methodological Best Practice. Journal of Management. 35. 10.1177/0149206308330560

[39] Rotharmel, F. T. \& Deeds, D. (2006), Alliance type, alliance experience and alliance management capability in high-technology ventures, Journal of Business Venturing 21 (2006) $429-460$ www. sciencedirect.com

[40] Sadeghinejad, Z., \& Najmaei, A. (2013). Top management team entrepreneurial behaviour: insights from team process. In M. Grimmer, \& R. Hecker (Eds.), Proceedings of the 27th ANZAM Conference 2013: managing on the edge (pp. 1-13). Australia: Australian and New Zealand Academy of Management.

[41] Schreiner, M. Kale, P. and Corsten, D (2009), what really is alliance management capability and how does it impact alliance outcomes and success? Strat. Mgmt. J., 30: 1395-1419 (2009) published online Wiley InterScience (www.interscience.wiley.com) DOI: 10.1002/smj.790 
[42] Teece, D. J., G. Pisano, \& A. Shuen (1997). Dynamic capabilities and strategic management. Strategic Management Journal, 18(7), 537-533. http://dx.doi.org/10.1002/(SICI)1097-0266(199708)18:7<509:: AID-SMJ882 > 3.0.CO;2-Z

[43] Teece, D. J. (2010). Business Models, Business Strategy and Innovation", Long Range Planning (Amsterdam: Elsevier Science) 43 (2010), 172-194.

[44] Teece, D. J., (2017), Dynamic Capabilities and (Digital) Platform Lifecycles, in Jeffrey Furman, Annabelle Gawer, Brian S. Silverman, Scott Stern (ed.) Entrepreneurship, Innovation, and Platforms (Advances in Strategic Management, Volume 37) Emerald Publishing Limited, pp.211 - 225

[45] Teece, D. J. (2018) Dynamic Capabilities as (workable) management systems theory Journal of Management \& Organization Volume 24, Issue 3 May 2018 , pp. 359-36 https://doi.org/10.1017/jmo. 2017.75

[46] Teece, D.J. (2018), Business models and Dynamic Capabilities Long Range Planning Volume 51, Issue 1, February 2018, Pages 40-49: Institute for Business Innovation, F402 Haas School of Business, \#1930, University of California, Berkeley, Berkeley, CA 94720-1930, USA https://doi.org/10.1016/j.lrp.2017.06. 007

[47] Torrington, D. Hall, L., Taylor, S. (2005), Human Resource Management FT Prentice Hall 978027368713 9 htps://books.google.co.ke

[48] Tripas, M. \& Gavetti, G. (2000) Capabilities, cognition, and inertia: evidence from digital imaging Strategic Management Volume 21, Issue 10-11 October - November 2000 Pages 1147-1161 https://doi. org/10.1002/1097-0266(200010/11)21:10/11<1147::AID-SMJ128>3.0.CO;2-R

[49] Vijande, L. S., Pérez M., Gutiérrez J.T. \& Rodríguez N.G (2012) Marketing Capabilities Development in Small and Medium Enterprises: Implications for Performance Journal of CENTRUM Cathedra Volume 5, Issue 1, 2012, 24-42

[50] Wang C.L, Senaratne, C. \& Rafig, M. (2015) Success Traps, Dynamic Capabilities and Firm Performance British Journal of Management Volume 26, Issue 1, Pages: 1-138 January 2015 https://doi.org/10.1111/ 1467-8551.12066

[51] Wernerfelt, B (1984), a Resource-Based View of the Firm Strategic Management Journal, Vol. 5, No. 2. (Apr. - Jun., 1984), pp. 171-180.

[52] Wimmer, R.D. and Dominick, J.R. (2006) Mass Media Research: An Introduction. 10th Edition, Wadsworth, Cengage Learning, Boston. Scientific Research

[53] Zahra, S. A., Sapienza, H. J. \& Davidson, P. (2006). Entrepreneurship and dynamic capabilities: a review, model, and research agenda. Journal of Management Studies, Vol.43, No. 3, p. 917 - 955.

[54] Ziggers, G. W. \& Tjemkes, B. (2010).Dynamics in Inter-Firm Collaboration: The Impact of Alliance Capabilities on Performance. Int. J. Food System Dynamics 2 (2010) 151-166

Citation: Gabriel Kitenga, et al. "Dynamic Capabilities and Sustainable Performance of Selected Manufacturing Firms in Kenya" International Journal of Managerial Studies and Research (IJMSR), vol 8, no. 1, 2020, pp. 42-56. doi: http://dx.doi.org/10.20431/23 49-0349.0801005.

Copyright: (C) 2020 Authors. This is an open-access article distributed under the terms of the Creative Commons Attribution License, which permits unrestricted use, distribution, and reproduction in any medium, provided the original author and source are credited. 